\title{
PENGARUH BELANJA INFRASTRUKTUR PEMERINTAH TERHADAP KAPITALISASI PASAR KELOMPOK INDUSTRI INFRASTRUKTUR, UTILITAS DAN TRANSPORTASI PADA PERUSAHAAN YANG TERDAFTAR DALAM BURSA EFEK INDONESIA (STUDI DATA TIME SERIES 2005-2014)
}

\author{
Deni Istiono*) \\ deni7533@gmail.com \\ Dosen Tetap Fakultas Ekonomi Universitas Majalengka
}

\begin{abstract}
This research aims to determine the effect of government infrastructure expenditure to market capitalization infrastructure, utilities and transportation industry of listed companies in the Indonesian Stock Exchange (IDX) during 2005-2014. Research analysis using descriptive and verification. Data used is time series data as realization of direct expenditures of government in infrastructure sector which consists of transportation and communication. Market capitalization data is capitalization of industry group infrastructure, utility and transportation companies listed on the Indonesian Stock Exchange (IDX) during 2005-2014. Analysis data used descriptive and verification. Descriptive analysis is used to describe the research variables development. The verification analysis used to examine the effect between variables with include the selection models test, specifications model test, normality test, regression test, coefficient determination test, statistical t and f test.

The result analysis showed government infrastructure expenditure variables is positive and significant impact on the market capitalization of the infrastructure, utilities and transportation industry listed companies in the Indonesian Stock Exchange during 2005-2014, with the determination level of $47.47 \%$ and the remaining $53.52 \%$ is explained by other variables that are not described or include in the research models function such as National income, inflation, exchange rates and others. Therefore central government should be consistent on each target and development activities that have been assigned in infrastructure expenditure every year. It is important to do, so the financing gap does not encourage inflation that couse high cost in the production process due to the inflation of infrastructure commodity. In addition, effective control efforts to development process is being carried out and also continue by synergy among the stakeholders that being implementation process development is done on time, as well as efforts to establish strategic policies and legal certainty for investors. So the investment climate more conducive to attracting private investors invest in the infrastructure, utilities and transportation sector in the Indonesian Stock Exchange.
\end{abstract}

Key words : MARKET CAPITALIZATION, INFRASTRUCTURE, UTILITIES AND TRANSPORTATION INDUSTRY, GOVERNMENT INFRASTRUCTURE EXPENDITURE, INDONESIAN STOCK EXCHANGE.

\section{PENDAHULUAN}

Investasi merupakan hasil biaya investasi yang ditentukan oleh kebijakan tingkat bunga dan pajak, serta harapan mengenai masa depan. Faktor-faktor penentu investasi sangat tergantung pada situasi dimasa depan yang sulit untuk diramalkan, oleh karenanya investasi merupakan komponen yang paling mudah berubah. Beberapa faktor yang mempengaruhi investasi dalam perekonomian suatu negara secara makro antara lain nilai tukar, tingkat suku bunga, inflasi, belanja pemerintah. (Paul A. Samuelson dan William D. Nordhaus ${ }^{10)}$., 1997:183) Dalam perkembangannya bentuk investasi dapat dilakukan dengan berbagai cara antara lain investasi di pasar modal. Pasar modal (capital market) merupakan pasar untuk berbagai instrumen keuangan jangka panjang 
yang bisa diperjualbelikan, baik dalam bentuk utang ataupun modal sendiri. Instrumeninstrumen keuangan yang diperjualbelikan di pasar modal seperti saham, obligasi, waran, right, obligasi konvertibel, dan berbagai produk turunan (derivatif) seperti opsi (put atau call).

Di dalam Undang-Undang Pasar Modal No. 8 Tahun 1995 ${ }^{14)}$, pengertian pasar modal dijelaskan lebih spesifik sebagai kegiatan yang bersangkutan dengan Penawaran Umum dan Perdagangan Efek, perusahaan publik yang berkaitan dengan Efek yang diterbitkannya, serta lembaga dan profesi yang berkaitan dengan Efek.Pasar modal memberikan peran besar bagi perekonomian suatu negara karena pasar modal memberikan dua fungsi sekaligus, fungsi ekonomi dan fungsi keuangan. Pasar modal dikatakan memiliki fungsi ekonomi karena pasar modal menyediakan fasilitas atau wahana yang mempertemukan dua kepentingan yaitu pihak yang memiliki kelebihan dana (investor) dan pihak yang memerlukan dana (issuer). Dengan adanya pasar modal maka perusahaan publik dapat memperoleh dana segar masyarakat melalui penjualan Efek saham melalui prosedur IPO atau efek utang (obligasi). Pasar modal dikatakan memiliki fungsi keuangan, karena pasar modal memberikan kemungkinan dan kesempatan memperoleh imbalan (return) bagi pemilik dana, sesuai dengan karakteristik investasi yang dipilih. Keputusan untuk berinvestasi pada pasar modal dipengaruhi oleh banyak faktor, salah satunya adalah tingkat kapitalisasi pasar perusahaan.

Kapitalisasi pasar merupakan salah satu daya tarik para investor dalam memilih saham. Semakin besar kapitalisasi pasar suatu saham, makin lama pula investor menahan kepemilikan sahamnya, karena investor menganggap bahwa perusahaan besar akan cenderung lebih stabil dari sisi keuangannya, resiko lebih kecil dan memiliki prospek yang bagus dalam jangka panjang dengan harapan return yang besar. Kapitalisasi pasar suatu perusahan sama halnya dengan investasi yang juga dipengaruhi oleh variabel makro ekonomi suatu negara seperti kebijakan fiskal berupa belanja pemerintah pada sektor tertentu. Belanja pemerintah merupakan belanja yang digunakan untuk membiayai kegiatan pembangunan pemerintah pusat baik yang dilaksanakan di pusat maupun daerah. Semakin besar belanja pemerintah pada fungsi dan sektor tertentu, menunjukkan bahwa pemerintah memiliki komitmen yang tinggi untuk mencapai target dan sasaran pembangunan yang telah ditetapkan. Sebagai negara berkembang, Indonesia saat ini sedang giat melakukan pembangunan disegala bidang termasuk sektor infrastruktur dan telekomunikasi yang merupakan subbagian dari belanja pemerintah berdasarkan fungsi ekonomi.

Salah satu arah kebijakan utama yang ditempuh pemerintah dalam rangka melaksanakan fungsi ekonomi pada tahun 2015 adalah meningkatkan belanja infrastruktur untuk memperkuat konektivitas nasional, mendukung sektor kemaritiman dan kelautan, menuju tercapainya kedaulatan pangan, kedaulatan energi dan ketenagalistrikan serta peningkatan industri dan pariwisata. Upaya-upaya ini dilakukan untuk mewujudkan kondisi fiskal yang sehat dan berkelanjutan terus dilaksanakan melalui peningkatan produktivitas APBN, penciptaan iklim investasi yang kondusif namun juga ramah terhadap lingkungan, penguatan fiscal buffer, serta pengelolaan keuangan negara yang fleksibel dan bijak.

Berdasarkan uraian diatas, maka dapat dijelaskan secara sederhana bahwa peran pemerintah melalui kebijakan fiskal berupa belanja infrastruktur diharapkan dapat mendorong iklim investasi yang kondusif termasuk di pasar modal. Adanya kepastian 
hukum melalui kebijakan APBN yang ditetapkan setiap tahunnya serta realisasi program-program pembangunan fisik (infrastruktur) tentunya akan mendorong minat investor untuk berinvestasi pada sektor ini karena kesempatan memperoleh imbalan (return), yang pada akhirnya mendorong peningkatan kapitalisasi pasar perusahaan yang termasuk dalam kelompok industri infrastruktur, utilitas dan transportasi.

\section{RUMUSAN MASALAH}

Berdasarkan uraian latar belakang diatas, rumusan masalah dalam penelitian ini sebagai berikut : adakah pengaruh belanja infrastruktur pemerintah terhadap kapitalisasi pasar kelompok industri infrastruktur, utilitas dan transportasi pada perusahaan yang terdaftar di Bursa Efek Indonesia (BEI) selama tahun 2005-2014.

\section{TUJUAN PENELITIAN}

Penelitian ini bertujuan untuk mengetahui pengaruh belanja infrastruktur pemerintah terhadap kapitalisasi pasar kelompok industri infrastruktur, utilitas dan transportasi pada perusahaan yang terdaftar di Bursa Efek Indonesia (BEI) selama tahun 2005-2014.

\section{KAJIAN PUSTAKA, PARADIGMA PENELITIAN DAN HIPOTESIS Kapitalisasi Pasar}

Rahardjo ${ }^{11)}$ (2006:41) mengemukakan bahwa kapitalisasi pasar (market capitalization) adalah nilai pasar dari saham yang diterbitkan (outstanding share) suatu emiten. Fakhruddin ${ }^{3)}$ (2008:115) mendefinisikan kapitalisasi pasar sebagai nilai besaran perusahaan publik yang telah mencatatkan sahamnya di bursa saham. Dengan demikian, besar tidaknya sebuah perusahaan di bursa saham adalah dengan melihat ukuran ini. Kapitalisasi pasar yang besar umumnya menjadi salah satu daya tarik para investor dalam memilih saham. Saham berkapitalisasi besar memiliki kapitalisasi pasar di atas Rp 1 triliun, saham berkapitalisasi medium dengan kapitalisasi pasar sebesar Rp 100 miliar sampai dengan kurang dari Rp 1 triliun, sedangkan saham berkapitalisasi kecil memiliki kapitalisasi pasar di bawah Rp 100 miliar (Manurung dan Rizky) , 2009:131).

Saham-saham dengan kapitalisasi pasar yang besar umumnya merupakan penggerak pasar (market mover) dan termasuk kedalam saham unggulan dan memiliki kelebihan dalam likuiditas perdagangan. Untuk menghitung kapitalisasi pasar, digunakan rumus sebagai berikut :

Kapitalisasi Pasar = Jumlah saham yang diterbitkan $\mathrm{x}$ harga saham

\section{Belanja Pemerintah}

Rostow dan Musgrave dalam Guritno Mangkoesoebroto ${ }^{8)}$ (1999:44) mengemukakan bahwa pada tahap awal perkembangan ekonomi, persentase investasi pemerintah terhadap total investasi sangat besar. Hal ini disebabkan oleh karena pada tahap ini pemerintah harus menyediakan prasarana. Peranan pemerintah tetap besar pada tahap menengah oleh karena peranan swasta yang semakin besar ini banyak menimbulkan kegagalan pasar. Dalam konteks perekonomian negara sedang berkembang, peranan kebijakan fiskal adalah untuk memacu laju pembentukan modal. Kebijakan fiskal juga memainkan peranan penting di dalam rencana pembangunan negara terbelakang. Di dalam perencanaan, suatu keseimbangan harus dicapai baik dalam arti riil maupun dalam arti uang. Dengan kata lain, rencana fisik harus 
disesuaikan dengan rencana keuangan. Penerapan rencana keuangan dan pencapaian perimbangan dalam arti riil dan keuangan jelas banyak tergantung pada tindakantindakan fiskal (Jhingan ${ }^{6}$, 1992:473).

Dasar hukum belanja Negara atau belanja pemerintah pusat adalah UndangUndang Dasar 1945 ${ }^{12)}$ yaitu bab VIII dari UU Dasar 1945 Amandemen IV Pasal 23 mengatur tentang APBN. Bunyi pasal 23 Ayat (1). Anggaran pendapatan dan belanja negara sebagai wujud dari pengelolaan keuangan negara ditetapkan setiap tahun dengan undang-undang dan dilaksanakan secara terbuka dan bertanggung jawab untuk sebesarbesarnya kemakmuran rakyat. Ayat (2), Rancangan undang-undang anggaran pendapatan dan belanja negara diajukan oleh Presiden untuk dibahas bersama Dewan Perwakilan Rakyat dengan memperhatikan pertimbangan Dewan Perwakilan Daerah. Ayat (3), Apabila Dewan Perwakilan Rakyat tidak menyetujui rancangan Anggaran Pendapatan dan Belanja Negara yang diusulkan oleh Presiden, Pemerintah menjalankan Anggaran Pendapatan dan Belanja Negara tahun yang lalu. APBN mempunyai fungsi otorisasi, perencanaan, pengawasan, alokasi, distribusi, dan stabilisasi. Semua penerimaan yang menjadi hak dan pengeluaran yang menjadi kewajiban negara dalam suatu tahun anggaran harus dimasukkan dalam APBN. Surplus penerimaan negara dapat digunakan untuk membiayai pengeluaran negara tahun anggaran berikutnya

Belanja negara adalah sebagaimana kewajiban pemerintah pusat yang diakui sebagai pengurang nilai kekayaan bersih yang terdiri atas belanja pemerintah pusat dan transfer ke pemerintah daerah dan dana desa (Pasal 1 Angka 8 UU Nomor 14 tentang APBN Tahun Anggaran 2016) ${ }^{13)}$. Belanja pemerintah pusat dikelompokkan menurut organisasi, fungsi dan program. Belanja pemerintah pusat menurut fungsi pada pasal 1 angka 10 Undang-Undang No.14 Tahun 2015 tentang APBN Tahun Anggaran 2016 adalah belanja pemerintah pusat untuk menjalankan fungsi pelayanan umum, fungsi pertahanan, fungsi ketertiban dan keamanan, fungsi ekonomi, fungsi lingkungan hidup, fungsi perumahan dan fasilitas umum, fungsi kesehatan, fungsi pariwisata, fungsi agama, fungsi pendidikan dan fungsi perlindungan sosial. Belanja infrastruktur dalam APBN termasuk dalam subbagian fungsi ekonomi sebagai berikut :

1. Perdagangan, Pengembangan Usaha, Koperasi dan UKM

2. Tenaga Kerja

3. Pertanian, Kehutanan, Perikanan, dan Kelautan

4. Pengairan

5. Bahan Bakar dan Energi

6. Pertambangan

7. Industri dan Konstruksi

8. Transportasi

9. Telekomunikasi

10. Litbang Ekonomi

11. Ekonomi Lainnya

\section{Paradigma Penelitian}

Paradigma atau kerangka konseptual dalam penelitian ini dapat ditunjukkan pada gambar 2.1 dibawah ini : 


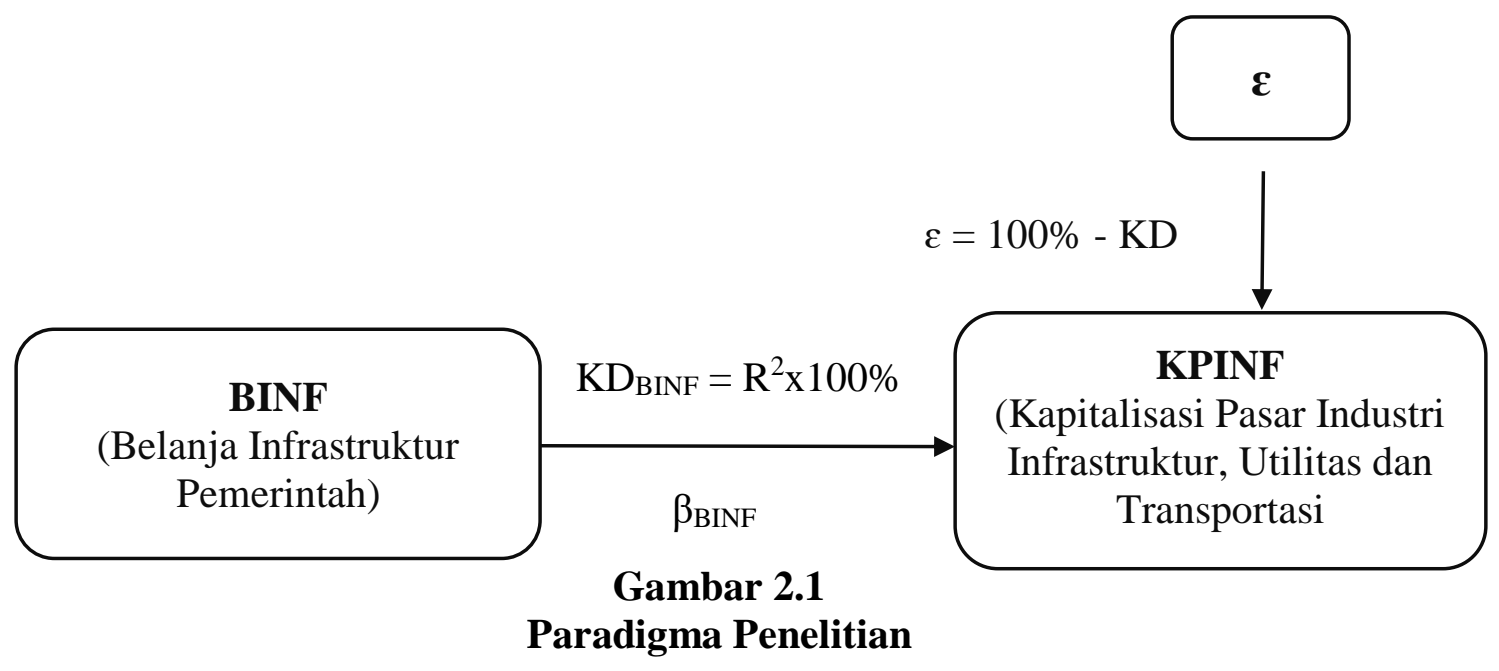

\section{Hipotesis}

Dalam penelitian ini peneliti merumuskan hipotesis sebagai jawaban sementara sebagai berikut : "Diduga bahwa belanja infrastruktur pemerintah berpengaruh terhadap kapitalisasi pasar kelompok industri infrastruktur, utilitas dan transportasi pada perusahaan yang terdaftar di Bursa Efek Indonesia (BEI) selama tahun 2005-2014.

\section{METODE PENELITIAN}

Mengacu pada tujuan penelitian maka dalam penelitian ini, peneliti menggunakan analisis deskriptif dan verifikatif. Analisis deskriptif digunakan untuk menggambarkan perkembangan variabel penelitian. Sedangkan analisis verifikatif digunakan untuk meneliti pengaruh antar variabel yang digunakan dalam penelitian. Klasifikasi variabel dalam penelitian ini adalah sebagai berikut :

1. Variabel bebas (independen), yaitu realisasi belanja langsung pemerintah dalam APBN pada sektor infrastruktur yang terdiri dari transpostasi dan komunikasi selama tahun 2005-2014 (dalam satuan Rp. Milyar)

2. Variabel terikat (dependen), yaitu nilai kapitalisasi pasar kelompok industri infrastruktur, utilitas dan transportasi pada perusahaan yang terdaftar pada Bursa Efek Indonesia (BEI) selama tahun 2005-2014 (dalam satuan Rp. Milyar).

Sumber pengumpulan data dalam penelitian ini yaitu data sekunder, yang merupakan data yang diambil dari dokumen publikasi Nota Keuangan Anggaran Pendapatan Belanja Negara (NKAPBN) Kementerian Keuangan RI ${ }^{9)}$ dan Statistik Bursa Efek Indonesia (IDX Statistic) ${ }^{5)}$ selama tahun 2005-2014.

Tahapan analisis verifikatif yang digunakan untuk memperoleh pengaruh variabel bebas terhadap terikat dalam penelitian ini dilakukan dengan melakukan uji pemilihan fungsi model regresi, uji kesalahan bentuk fungsi model regresi, uji normalitas, uji regresi sederhana, uji koefisien determinasi, selanjutnya uji hipotesis statistik untuk memperoleh kesimpulan. Analisis verifikatif dilakukan dengan bantuan perangkat lunak (software) komputer olah data Eviews versi 04. Adapun tahapan analisis verifikatif dapat digambarkan sebagai berikut : 


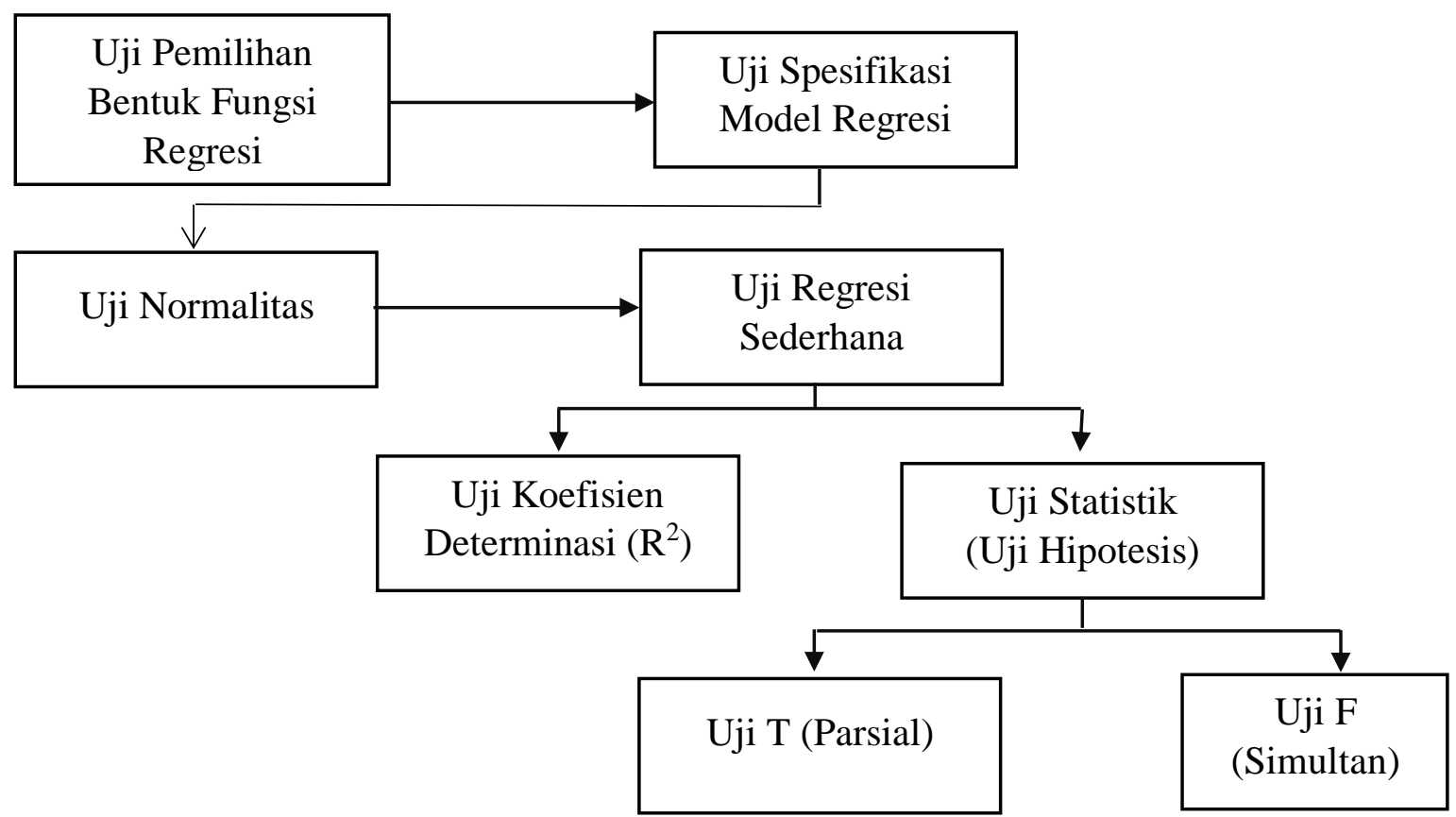

Gambar 3.1

Tahapan Analisis Verifikatif

\section{HASIL PENELITIAN DAN PEMBAHASAN}

\section{Analisis Deskriptif}

Perkembangan kapitalisasi pasar kelompok industri infrastruktur, utilitas dan transportasi pada perusahaan yang terdaftat di BEI selama tahun 2005-2014 secara umum mengalami volatilitas yang relatif tinggi. Volatilitas ini ditunjukkan oleh fase dimana fluktuasi relatif tinggi dan kemudian dikuti oleh fluktuasi yang rendah dan kembali tinggi. Kondisi ini dapat dilihat pada tahun 2005 sampai tahun 2008. Tahun 2009 sampai 2014 kecenderungan peningkatan terus terjadi, meskipun mengalami penurunan pada tahun 2011. Jika diamati selama 10 tahun terakhir rata-rata kapitalisasi pasar kelompok industri infrastruktur, utilitas dan transportasi mencapai Rp. 475,214 Milyar dengan capaian tertinggi pada tahun 2006 sebesar Rp.771,644 Milyar dan terendah terjadi pada tahun 2005 sebesar Rp. 207,852 Milyar. Secara grafis perkembangan kapitalisasi pasar kelompok industri infrastruktur, utilitas dan transportasi dan belanja infrastruktur pemerintah selama tahun 2005-2014 dapat dilihat $\begin{array}{lllll}\text { pada } & \text { gambar } & 4.1 & \text { dibawah }\end{array}$ 


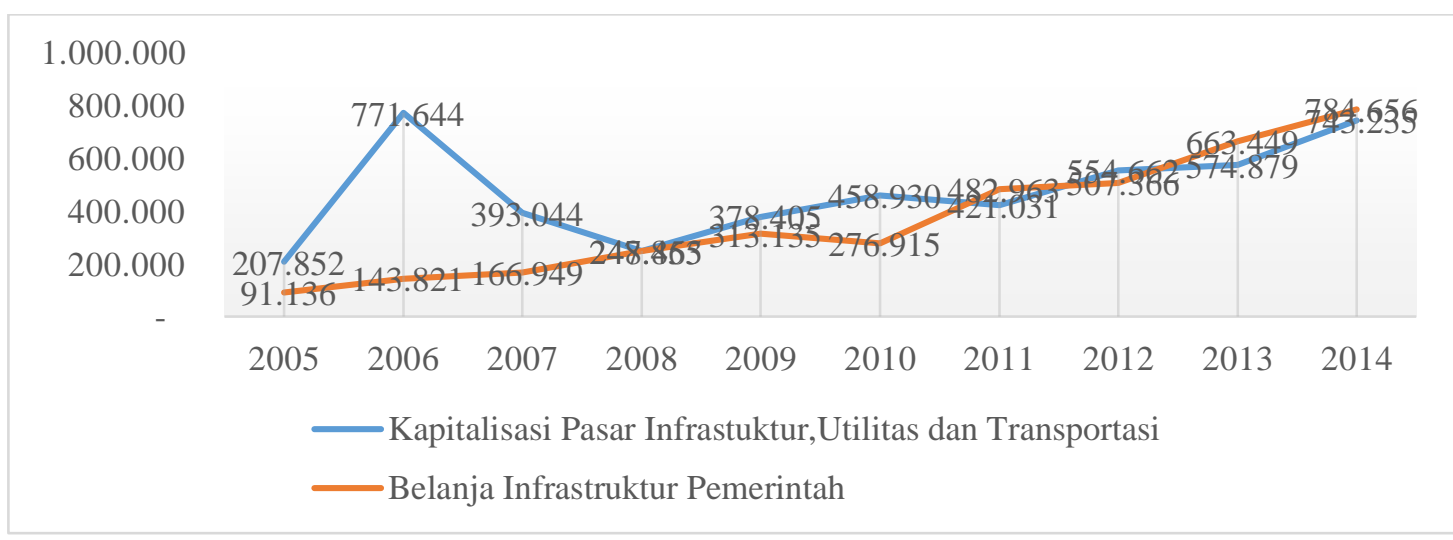

\section{Gambar 4.1 \\ Perkembangan Kapitalisasi Pasar Kelompok Industri Infrastruktur, Utilitas dan Transportasi serta Belanja Infrastruktur Pemerintah, Tahun 2005-2014}

Pada gambar 4.1 diatas perkembangan belanja infrastruktur pemerintah justru mengalami peningkatan yang signifikan. Tercatat penurunan terjadi hanya pada tahun 2010, namun selanjutnya terus meningkat sampai tahun 2014. Jika diamati, rata-rata belanja infrastruktur pemerintah selama 10 tahun terakhir mencapai Rp. 397,826 Milyar pertahun, dimana belanja tertinggi terjadi pada tahun 2014 senilai 743,235 Milyar dan terendah pada tahun 2005 senilai Rp. 91,146 Milyar. Tingginya belanja infrastruktur pemerintah ini terjadi dapat difahami karena mengingat arah kebijakan fiskal fungsi ekonomi dimana infstruktur menjadi subbagiannya ditujukan untuk upaya percepatan pertumbuhan ekonomi yang berkualitas dengan memperkuat daya tahan ekonomi yang didukung oleh pembangunan transportasi, pertanian, infrastruktur, dan energi didanai melalui pengalokasian anggaran pada fungsi ekonomi. Upaya ini sudah dilakukan sejak tahun 2014 antara lain dengan adanya pemotongan belanja pada beberapa Kementerian /Lembaga yang membawahi fungsi ekonomi, seperti pada Kementerian Pekerjaan Umum, Kementerian Perhubungan, Kementerian Energi dan Sumber Daya Mineral,Kementerian Pertanian, dan Kementerian Kelautan dan Perikanan. Namun demikian turunnya alokasi anggaran fungsi ekonomi tersebut diharapkan tidak mengganggu pencapaian sasaran yang diharapkan.

\section{Analisis Verifikatif}

\section{Uji Pemilihan Model}

Pemilihan bentuk fungsi model empiris yang baik sangat diperlukan untuk menentukan implikasi yang penting dalam rangkaian kerja hasil analisis selanjutnya. Kesalahan dalam bentuk fungsi akan menyebabkan persoalan kesalahan spesifikasi dan estimasi-estimasi koefisien akan bias, dan parameter estimasi tidak akan konsisten (Insukindro ${ }^{4}$, dkk, 2001:56). Pengujian model empiris dalam penelitian ini dilakukan dengan menggunakan uji MacKinon, White and Davidson (MWD test) dengan pedoman jika $Z_{1}$ signifikan secara statistik maka hipotesis nol yang menyatakan bahwa model yang benar adalah bentuk lin-lin ditolak dan sebaliknya, jika $Z_{2}$ signifikan secara statistik, maka hipotesis alternatif yang menyatakan bahwa model yang benar log-lin (double log) ditolak 
Tabel 4.1

Ringkasan Hasil MWD test

\begin{tabular}{|l|l|l|l|l|l|l|}
\hline \multirow{2}{*}{ Variabel } & \multicolumn{4}{|l|}{ Model Lin-Lin } & \multicolumn{3}{l|}{ Model Log-Lin } \\
\cline { 2 - 7 } & Koefisien & t-statistik & Prob & Koefisien & t-statistik & Prob \\
\hline $\mathrm{Z}$ & 392845.1 & 0.330786 & 0.7505 & $-4.16 \mathrm{E}-06$ & -0.547182 & 0.6013 \\
\hline
\end{tabular}

Sumber: Data diolah

Berdasarkan tabel 4.1 diatas, dapat disimpulkan bahwa pada tingkat derajat kepercayaan 95\% $(\alpha=5 \%)$, model Lin-Lin maupun Log-Lin kedua-duanya baik atau layak digunakan sebagai model regresi untuk menaksir pengaruh belanja infrastruktur terhadap kapitalisasi pasar industri infrastruktur pada perusahaan yang terdaftar pada Bursa Efek Indonesia. Nilai koefisien dan t-statistik serta probabilitas $Z_{1}$ dan $Z_{2}$ tidak signifikan secara statistik, yang berarti bahwa hipotesis alternatif yang menyatakan bahwa model yang benar adalah linier dan log linier diterima. Berdasarkan hasil $M W D$ test tersebut, maka analisis regresi selanjutnya dalam penelitian ini dilakukan dengan model Log-Lin dengan pendekatan kuadrat terkecil $(O L S)$.

\section{Uji Kesalahan Spesifikasi Model}

Uji ini pada dasarnya untuk mengetahui linieritas model yang digunakan dalam penelitian yaitu model Log-Linier. Uji spesifikasi model dilakukan untuk mengetahui spesipikasi model yang digunakan sudah benar atau salah atau tidak (Agus Widarjono $^{1)}$., 2007:186) Salah satu metode yang dapat digunakan untuk menguji linieritas model adalah dengan menggunakan uji Ramsey RESET (Regression Spesification Error Test $=$ RESET) yang dikembangkan oleh J.B Ramsey (Insukindro, dkk, 2001:100). Hasil pengujian Ramsey RESET dapat dilihat pada secara ringkas pada tabel 4.2 berikut :

Tabel 4.2

Ramsey RESET Test:

\begin{tabular}{|c|c|c|c|}
\hline F-statistic & 0.0810287 & Probability & 0.783812 \\
\hline Log likelihood ratio & 0.115455 & Probability & 0.734017 \\
\hline
\end{tabular}

Dari ringkasan yang tersaji pada tabel 4.2 di atas terlihat bahwa nilai $\mathrm{F}_{\text {-hitung }}$ sebesar 0,0810287 sedangkan nilai $\mathrm{F}_{\text {-tabel }}$ dengan degree of freedom (pembilang $=\mathrm{k}-1=$ 3-1 = 2 dan penyebut $=\mathrm{n}-\mathrm{k}=10-3=7$ ) pada $\alpha=0,05$ adalah 8,89 . Hipotesisnya adalah jika $\mathrm{F}_{\text {-hitung }}>\mathrm{F}_{\text {-tabel }}$, maka hipotesis nol yang menyatakan bahwa spesipikasi model yang benar adalah log-linier ditolak dan sebaliknya jika $F_{\text {-hitung }}<\mathrm{F}_{\text {-tabel }}$, maka hipotesis nol yang menyatakan bahwa spesipikasi model yang benar adalah log-linier diterima. Dengan demikian dapat disimpulkan bahwa spesifikasi model yang penelitian yang menggunakan bentuk fungsi log-linier (log-lin) sudah benar.

\section{Uji Normalitas}

Uji ini dilakukan untuk mengetahui apakah faktor pengganggu (residual) berdistribusi normal atau tidak. Uji ini penting dilakukan karena pengujian uji t-statistik dan f-statistik hanya bisa diaplikasikan jika residual memiliki distribusi normal (Agus Widarjono $^{1)}$., 2007:53) Berdasarkan pengujian yang dilakukan, hasil analisis statistik 
Jarque-Bera normality test statistics yang diperoleh adalah 1,392304. Bila dibandingkan dengan $\chi^{2}$-tabel $(\alpha=0,05 ; 2)=5,99146$, maka hipotesis nol tidak dapat ditolak karena $\chi^{2}$-hitung $<\chi^{2}$-tabel. Artinya bahwa model empiris yang digunakan mempunyai residual atau faktor penggangu yang berdistribusi normal.

\section{Uji Regresi}

Uji regresi dilakukan untuk memenuhi tujuan penelitian yaitu mengetahui pengaruh belanja infrastruktur pemerintah terhadap variabel kapitalisasi pasar industri infrastruktur,utilitas dan transportasi pada perusahaan yang tercatat di Bursa Efek Indonesia selama tahun 2005-2014. Adapun hasil uji regresi model log-liner dapat dilihat pada tabel 4.3 dibawah ini :

\section{Tabel 4.3}

Hasil Uji Regresi

\begin{tabular}{|c|c|c|c|c|}
\hline \multicolumn{5}{|c|}{$\begin{array}{l}\text { Dependent Variable: LNKPINF } \\
\text { Method: Least Squares } \\
\text { Date: } 12 / 03 / 15 \text { Time: } 21: 41 \\
\text { Sample: } 20052014 \\
\text { Included observations: } 10\end{array}$} \\
\hline Variable & Coefficient & Std. Error & $\mathrm{t}-$ Statistic & Prob. \\
\hline $\begin{array}{l}\text { C } \\
\text { BINF }\end{array}$ & $\begin{array}{l}12.61476 \\
3.03 \mathrm{E}-06 \\
\end{array}$ & $\begin{array}{l}0.230634 \\
5.38 \mathrm{E}-07 \\
\end{array}$ & $\begin{array}{l}54.69609 \\
5.63197 \\
\end{array}$ & $\begin{array}{l}0.0000 \\
0.0413\end{array}$ \\
\hline $\begin{array}{l}\text { R-squared } \\
\text { Adjusted R-squared } \\
\text { S.E. of regression } \\
\text { Sum squared resid } \\
\text { Log likelihood } \\
\text { Durbin-Watson stat }\end{array}$ & $\begin{array}{l}0.689213 \\
0.529614 \\
0.375105 \\
1.125631 \\
-3.268177 \\
2.421458\end{array}$ & $\begin{array}{l}\text { Mean d } \\
\text { S.D. de } \\
\text { Akaike } \\
\text { Schwar } \\
\text { F-statist } \\
\text { Prob(F- }\end{array}$ & $\begin{array}{l}\text { pendent var } \\
\text { endent var } \\
\text { nfo criterion } \\
\text { criterion } \\
\text { c } \\
\text { tatistic) }\end{array}$ & $\begin{array}{l}12.99432 \\
0.427365 \\
1.053635 \\
1.114152 \\
33.82460 \\
0.001260\end{array}$ \\
\hline
\end{tabular}

Sumber: Data diolah

Berdasarkan tabel 4.3 diatas, maka persamaan hasil regresi model log-linier dalam penelitian ini dapat dituliskan sebagai berikut :

$$
\mathrm{LNKPI}=12.64176+3.03 \mathrm{E}-06 \mathrm{BINF}+\dot{\varepsilon}
$$

\section{Uji Koefisien Determinasi $\left(\mathbf{R}^{2}\right)$}

Uji ini merupakan interpretasi ketepatan perkiraan yang menunjukkan seberapa besar persentase variasi variabel penjelas dapat menjelaskan variasi variabel yang dijelaskan. Dari hasil estimasi regresi (lihat tabel 4.3) diperoleh $\mathrm{R}^{2}$ sebesar 0,689. Untuk menghitung determinasi variabel belanja infrastruktur pemerintah terhadap variabel kapitalisasi pasar industri infrastruktur,utilitas dan transportasi pada perusahaan yang tercatat di Bursa Efek Indonesia digunakan rumus sebagai berikut : (Dadang Sudirno dan Devi Vian Nurvianti ${ }^{2}$, 2015:32)

$$
\begin{aligned}
\mathrm{KD} & =\mathrm{R}^{2} \times 100 \% \\
& =0,689^{2} \times 100 \% \\
& =47,48 \%
\end{aligned}
$$

Berdasarkan hasil perhitungan tersebut maka dapat diartikan bahwa 47,48\% variasi perubahan variabel terikat (kapitalisasi pasar industri infrastruktur,utilitas dan 
transportasi) mampu dijelaskan oleh variasi perubahan variabel bebas (belanja infrastruktur pemerintah), sisanya sebesar 53,52\% diterangkan oleh variabel diluar model penelitian yang terangkum dalam kesalahan random.

\section{Uji t-statistik}

Pengujian ini pada dasarnya menunjukkan seberapa jauh pengaruh satu variabel penjelas secara individual dalam menerangkan variasi variabel terikat. Berdasarkan hasil regresi dengan menggunakan variabel bebas belanja infrastruktur pemerintah dapat dilakukan uji parameter dengan kriteria keputusan sebagai berikut :

- $\mathrm{H}_{0}: \beta_{2} \leq 0$, di mana secara individu variabel belanja infrastruktur pemerintah tidak berpengaruh secara signifikan terhadap kapitalisasi pasar industri infrastruktur,utilitas dan transportasi pada perusahaan yang tercatat di Bursa Efek Indonesia selama tahun 2005-2014.

- $\mathrm{H}_{\mathrm{a}}: \beta_{2}>0$, di mana secara individu variabel belanja infrastruktur pemerintah berpengaruh secara signifikan terhadap kapitalisasi pasar industri infrastruktur,utilitas dan transportasi pada perusahaan yang tercatat di Bursa Efek Indonesia selama tahun 2005-2014.

Dari hasil perhitungan diperoleh nilai $t_{\text {-hitung }}$ sebesar 5,63197 dan $t_{\text {-tabel }}$ sebesar 1,812 pada $\alpha=5 \%(0,05 ; 10)$ dengan melakukan pengujian satu sisi berarti nilai $t_{\text {-hitung }}>t_{\text {- }}$ tabel atau $\mathrm{H}_{\mathrm{a}}$ diterima dan $\mathrm{H}_{0}$ ditolak. Hal ini berarti bahwa variabel belanja infrastruktur pemerintah berpengaruh secara signifikan berarah positif terhadap kapitalisasi pasar industri infrastruktur,utilitas dan transportasi pada perusahaan yang terdaftar di Bursa Efek Indonesia dan hasil pengujian sesuai dengan hipotesis.

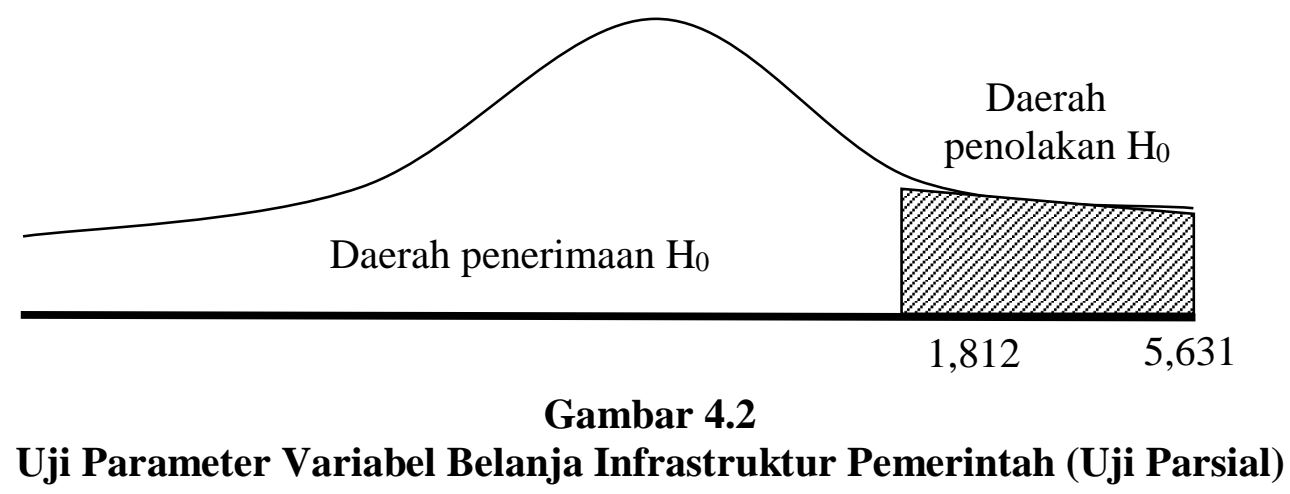

\section{Uji F-statistik}

Pengujian ini pada dasarnya menunjukkan apakah semua variabel bebas yang dimasukan dalam model mempunyai pengaruh secara bersama-sama terhadap variabel terikat. Hasil perhitungan regresi model terpilih yang tersaji pada tabel 4.3 menunjukkan bahwa nilai $F_{\text {-hitung }}$ adalah 33,82460 sedangkan $\mathrm{F}_{\text {-tabel }} \alpha 5 \%$ (n-k) (k-1) atau $(0,05 ; 8 ; 1)$ adalah 5,32 . Artinya $\mathrm{F}_{\text {-hitung }}>\mathrm{F}_{\text {-tabel }}$ sehingga hipotesis nol ditolak dan hipotesis alternatif diterima, maka hipotesis yang menyatakan bahwa semua variabel bebas secara bersama-sama dan signifikan mempengaruhi variabel terikat diterima. Dengan kata lain, variabel belanja infrastruktur pemerintah secara bersama-sama mampu menjelaskan variabel kapitalisasi pasar industri infrastruktur,utilitas dan 
transportasi pada perusahaan yang tercatat di Bursa Efek Indonesia selama periode penelitian.

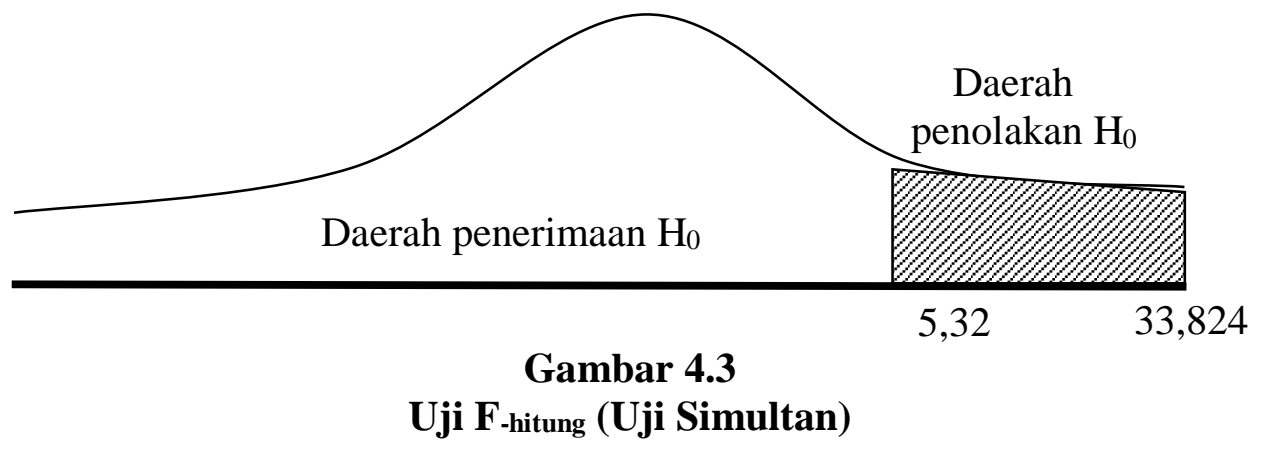

\section{Pembahasan}

Berdasarkan hasil regresi yang tersaji pada tabel 4.3, diperoleh persamaan hasil regresi model log-linier sebagai berikut :

$$
\mathrm{LNKPI}=12.64176+3.03 \mathrm{E}-06 \mathrm{BINF}+\dot{\varepsilon}
$$

Dari persamaan model regresi tersebut dapat dijelaskan sebagai berikut :

1. Koefisien konstanta sebesar 12.64176 memberikan arti bahwa jika perubahan belanja infrastruktur pemerintah tetap, maka kapitalisasi pasar industri infrastruktur,utilitas dan transportasi pada perusahaan yang terdaftar di Bursa Efek Indonesia akan mengalami perubahan yang positif sebesar 12 persen dengan asumsi ceteris paribus.

2. Koefisien variabel bebas belanja infrastruktur pemerintah sebesar 3.03E-06 memberikan arti bahwa kenaikan belanja pemerintah pada sektor infratruktur sebesar 1 persen akan mendorong peningkatan kapitalisasi pasar industri infrastruktur, utilitas dan transportasi pada perusahaan yang terdaftar di Bursa Efek Indonesia sebesar 3,03 persen dengan asumsi ceteris paribus. Hasil ini memberi makna bahwa peran pemerintah dalam upaya pembangunan melalui anggaran atau belanja pada sektor infrastruktur baik transportasi dan komunikasi akan menstimulasi pasar saham di Indonesia terutama kapitalisasi pasar kelompok industri infrastruktur, utilitas dan transportasi. Dengan demikian, secara sederhana dapat dikatakan bahwa belanja infrastruktur pemerintah secara tidak langsung akan menstimulan hasrat investor untuk berinvestasi di sektor ini. Hal ini membuktikan pendapat Jhingan ${ }^{6)}$ (1992:473) yang mengemukakan bahwa perekonomian negara sedang berkembang, melalui kebijakan fiskal adalah untuk memacu laju pembentukan modal. Lebih lanjut Jhingan mengemukakan bahwa kebijakan fiskal melalui pendapatan dan belanja negara memainkan peranan penting didalam rencana pembangunan. Dimana dalam perencanaan, suatu keseimbangan harus dicapai baik dalam arti riil maupun dalam arti uang. Dengan kata lain, rencana fisik harus disesuaikan dengan rencana keuangan. Penerapan rencana keuangan $(\mathrm{APBN})$ dan pencapaian perimbangan dalam arti riil dan keuangan jelas banyak tergantung pada tindakan-tindakan fiskal.

Berdasarkan hasil penelitian dan pembahasan diatas, dapat digambarkan sebagai berikut : 


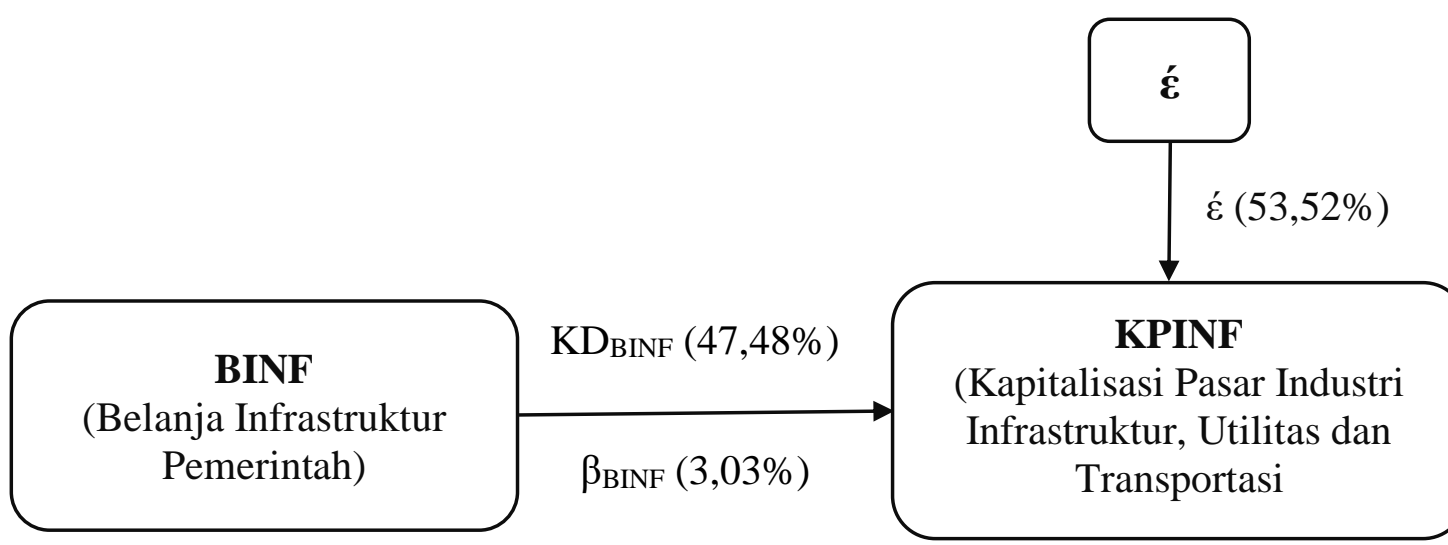

\section{Gambar 4.4 \\ Hasil Penelitian Pengaruh Belanja Infrastruktur Pemerintah terhadap Kapitalisasi Pasar Industri Infrastrukur, Utilitas dan Transportasi}

\section{KESIMPULAN DAN SARAN \\ Kesimpulan}

Berdasarkan hasil penelitian yang telah dilakukan, maka peneliti mengambil kesimpulan sebagai berikut :

1. Variabel belanja infrastruktur pemerintah berpengaruh positif dan signifikan terhadap kapitalisasi pasar industri infrastruktur, utilitas dan transportasi pada perusahaan yang terdaftar di Bursa Efek Indonesia. Ini berarti semakin meningkat belanja pemerintah pada sektor infratruktur maka semakin meningkat pula tingkat kapitalisasi pasar industri infrastruktur, utilitas dan transportasi pada perusahaan yang tercatat di Bursa Efek Indonesia dan sebaliknya. Hal ini karena kebijakan fiskal melalui APBN yang ditetapkan setiap tahunnya menjadi salah satu indikator investor untuk melakukan investasi di Indonesia, sehingga akan memacu laju pembentukan modal (investasi) secara agregat.

2. Determinasi variabel belanja infrastruktur pemerintah terhadap kapitalisasi pasar industri infrastruktur, utilitas dan transportasi pada perusahaan yang tercatat di Bursa Efek Indonesia adalah sebesar 47,47\% dan sisanya 53,52\% dijelaskan oleh variabel lain yang tidak dijelaskan dalam model penelitian seperti pendapatan negara, inflasi, nilai tukar dan lain-lain.

\section{Saran}

Berdasarkan kesimpulan diatas, maka peneliti dapat memberikan saran sebagai berikut :

1. Pemerintah pusat harus konsisten dan tetap pada jalur (on the track) pada setiap sasaran dan kegiatan pembangunan yang telah ditetapkan dalam belanja infrastruktur melalui APBN setiap tahunnya. Hal ini penting dilakukan agar financing gap yang terjadi dalam pembangunan infrastruktur tidak melahirkan high cost dalam proses produksi karena inflasi komoditas infrastruktur. Selain itu, upaya pengawasan efektif terhadap proses pembangunan fisik yang sedang dilaksanakan juga harus kontiyu dan sinergis antar stake holder agar proses pelaksanaan pembangunan fisik yang dilakukan tepat waktu, termasuk juga upaya menetapkan kebijakan-kebijakan strategis dan kepastian hukum bagi investor. Sehingga iklim 
investasi menjadi lebih kondusif dalam menarik minat investor swasta berinvestasi disektor infrastruktur, utilitas dan transportasi di Bursa Efek Indonesia.

2. Upaya peningkatan kapitalisasi pasar di pasar modal termasuk kelompok industri infrastruktur, utilitas dan transportasi tidak hanya dipengaruhi oleh belanja infrastruktur pemerintah, tetapi juga variabel-variabel makro ekonomi lainnya. Untuk itu, asumsi makro yang dijadikan acuan dalam nota keuangan APBN 2015 misalnya upaya pencapaian pertumbuhan ekonomi Nasional rata-rata diatas 5,8 persen, inflasi yang diperkirakan terkendali pada kisaran 4,4 persen dan nilai tukar rupiah yang bergerak stabil pada kisaran Rp. 11.900,- per dolar Amerika Serikat, harus dapat dicapai sesuai target yang telah ditetapkan. Hal ini penting dilakukan, karena akan menjadi salah satu indikator keputusan investor dalam melakukan investasi di pasar modal. Dimana pasar modal saat ini mempunyai peran penting untuk mendukung pendanaan dan pembiayaan pembangunan yang akan dilaksanakan di Indonesia.

\section{DAFTAR PUSTAKA}

Agus Widarjono, 2007. Ekonometrika Teori dan Aplikasi untuk Ekonomi dan Bisnis, Yogyakarta, Ekonisia FE UII

Dadang Sudirno dan Devi Vian Nurvianti, 2015. Konflik Peran dan Kelelahan

Emosional Pengaruhnya Terhadap Kinerja Dosen Pada Universitas Majalengka, Jurnal Ilmiah Manajemen dan Akuntansi (MAKSI) Hal 25-43. Volume.2 Nomor.1 Juni 2015.

Fakhruddin, Hendy M. 2008. Istilah Pasar Modal A-Z. Jakarta, PT. Elex Media Komputindo.

Insukindro, Maryatmo, R dan Aliman, 2001. Modul Ekonometrika Dasar dan Penyusunan Indikator Unggulan Ekonomi, Lokakarya ekonometrika dalam Rangka Penjajakan Leading indikator Ekspor di KTI.

Indonesia Stock Exchange Yearly Statistic, http://www.idx.co.id/idid/beranda/publikasi/statistik.aspx. (berbagai terbitan)

Jhingan, ML.1992. Ekonomi Pembangunan dan Perencanaan (terjemahan), Jakarta, CV Rajawali.

Manurung, Adler H. dan Lutfi T. Rizky. 2009. Successful Financial Planner: A Complete Guide. Jakarta, PT. Grasindo

Mangkoesoebroto, Guritno, 1999. Ekonomi Publik Edisi 3, Yogyakarta, BPFE UGM

Nota Keuangan APBN Republik Indonesia, www.kemenkeu.go.id/id-id/anggaran.depkeu. (berbagai terbitan).

Paul A. Samuelson dan William D. Nordhaus, 1997. Makro Ekonomi Edisi Keempat Belas Jakarta, Erlangga.

Rahardjo Sapto, 2006. Kiat Membangun Aset Kekayaan. Jakarta, PT. Elex Media Komputindo.

Undang-Undang Dasar 1945.

Undang-Undang Nomor. 14 Tahun 2015 tentang APBN Tahun Anggaran 2016.

Undang-Undang Nomor 8 Tahun 1995 tentang Pasar Modal 